\title{
Occupational exposure to cytotoxic drugs: the importance of surface cleaning to prevent or minimise exposure
}

\author{
Susana Viegas ${ }^{1,2}$, Ana Cebola de Oliveira ${ }^{3}$, Elisabete Carolino $^{1}$, and Mário Pádua ${ }^{1}$ \\ H\&TRC- Health \& Technology Research Center, ESTeSL - Escola Superior de Tecnologia da Saúde, Instituto \\ Politécnico de Lisboal, Centro de Investigação em Saúde Pública, Escola Nacional de Saúde Pública, Universidade \\ NOVA de Lisboa², NOVA Medical School, Faculdade de Ciências Médicas, Universidade NOVA de Lisboa ${ }^{3}$, \\ Lisbon, Portugal
}

[Received in April 2018; Similarity Check in April 2018; Accepted in August 2018]

Healthcare workers who prepare or administer cytotoxic agents run the risk of exposure, and the risks for health are real even at doses lower than those applied in cancer patients, because, in theory, no dose is safe. The most common and problematic route of exposure is through the skin, especially as work surfaces can remain contaminated even after cleaning. This pilot study aimed to demonstrate the importance of having an effective surface decontamination protocol by determining surface contamination with cyclophosphamide, 5 -fluorouracil, and paclitaxel as the most common cytotoxic drugs in an oncology day service. Samples were collected before and after drug handling and analysed with high performance liquid chromatography with diode array detection (HPLC-DAD). Of the 29 samples collected before drug handling 23 were contaminated, five of which with more than one drug. Of the 30 samples collected after drug handling 25 were contaminated, eight of which with more than one drug. The two time points did not significantly differ, which evidences a widespread contamination and ineffective cleaning. This calls for revising the cleaning protocol and handling procedure to place contamination under control as much as possible.

KEY WORDS: 5-fluoroacil; contamination control; cyclophosphamide; HPLC-DAD; oncology day service; paclitaxel

Cytotoxic drugs have been recognised as hazardous to healthcare professionals such as medical doctors, oncology nurses, pharmacists, and other staff, including maintenance, since the late 1970s (1). The European Agency for Safety and Health at Work (EU-OSHA) (2) and the European Commission Directorate-General for Employment, Social Affairs, and Inclusion (3) are well aware of the issue, but the legislation of the member states still has not been harmonised in terms of risk prevention in the healthcare sector (4). The EU legislation, however, does require from employers to provide a monitoring programme for carcinogenic compounds, which includes most of the cytotoxic drugs (4).

Essentially, their mechanism of action comes down to inhibiting tumour growth and cell division by interfering with the cell genetic material. However, the most common cytotoxic drugs are not specific enough to target tumour cells alone, but they also affect healthy cells of the exposed individuals (5-11). This can lead to genotoxic effects that can result in gene alterations and neoplasms in healthy population or secondary tumours in treated cancer patients $(7,9,12)$.

Correspondence to: Susana Patrícia Costa Viegas, ESTeSL - Escola Superior de Tecnologia da Saúde, Instituto Politécnico de Lisboa, Lisbon, Portugal; Av. D. João II, Lote 4.69.01, Lisboa, Portugal

E-mail: susana.viegas@estesl.ipl.pt
Even exposure to doses lower than those received by cancer patients can produce adverse health effects, especially in chronically exposed healthcare workers (1316). There have been reports of reproductive toxicity that can result in miscarriage, temporary or permanent infertility, preterm births, congenital malformations, and learning disabilities in the children of the exposed individuals (17, 18). In addition, long-term occupational exposure has been associated with increased risk of hair loss, infections (attributed to lower white blood cell count and immunosuppression), organ toxicity (e.g. liver, kidney, lung, and cardiac toxicity), myelotoxicity, mucosal ulcers, fatigue, bleeding, and headaches (19). Furthermore, occupationally exposed individuals have a higher incidence of DNA damage, chromosomal abnormalities, and cancer consistent with the inherent carcinogenic properties of these drugs $(15,20,21)$.

Exposure can occur at every stage of the cytotoxic drug lifecycle: from production and distribution to its application in hospital or home care settings and its disposal as waste. The risk of exposure is not limited to healthcare workers who prepare (pharmacists and pharmacy technicians) or administer (nurses) cytotoxic agents. Anyone in touch with contaminated air or objects or even patient excreta is at risk (12, 22-26). One Dutch study (25) identified home care, nursing homes, and laundry facilities as non-hospital occupational settings with higher exposure, which were all 
related to the care of cancer patients. Clearly, a large number of workers can be exposed to cytotoxic agents in three ways: through inhalation of aerosolised drugs; through direct skin contact, and rarely through ingestion from contaminated hands and gloves (27). However, thanks to advanced protection technology available at the workplaces, such as biological safety cabinets, the most common and problematic route of exposure is skin $(4,28)$.

Yet, even with improvements in safe handling practices exposure to cytotoxic drugs is still a threat. Some studies reported traces of several cytotoxic drugs on work surfaces serving for receiving, storing, preparing, and validating preparations in hospital pharmacies (29-33) and even on surfaces in administration areas $(33,34)$. Some reported cytotoxic drugs in biological samples (blood and urine) from healthcare workers $(19,35-37)$ and some reported contamination of work surfaces even after their cleaning $(4,37-40)$.

The aim of this pilot study was therefore to establish working surface contamination with cytotoxic drugs in an outpatient oncology setting and see how effective the adopted standard decontamination procedures are.

\section{MATERIALS AND METHODS}

Our study focused on the drug preparation unit and the drug administration unit of an oncology day service (ODS), which treated 375 patients (over 3145 visits) in 2015. It also included the toilets used by patients and their accompanying family members, who also run the risk of exposure (Figure 1).

Before sampling began, we gathered information about the number of chemotherapies prepared, most common drugs used, application methods, and post-treatment cleaning procedures. We also asked the staff to carry on cleaning as usual to avoid bias. For sampling we chose a day regarded as »normal « by the staff in terms of the number of treatments. Samples from the working and other surfaces were taken with wipes (24).

The preparation unit had four pharmacists, three pharmacy technicians, and four assistants. It did not use a closed-system drug transfer device and had only two biosafety cabinets to prepare the cytotoxic drugs, but only used one at a time. The cytotoxic drugs in this unit were handled as follows: pharmacists would send the drugs to pharmacy technicians to prepare them in one of the biosafety cabinets and then check the preparations. Then the assistants would carry the preparations in a specific container similar to a biohazard box to the drug administration unit (Figure 1).

The administration unit had thirteen infusion chairs and three beds (plus two if needed) attended by 14 nurses and seven assistants. There was also a reception desk for patient registration on visits.

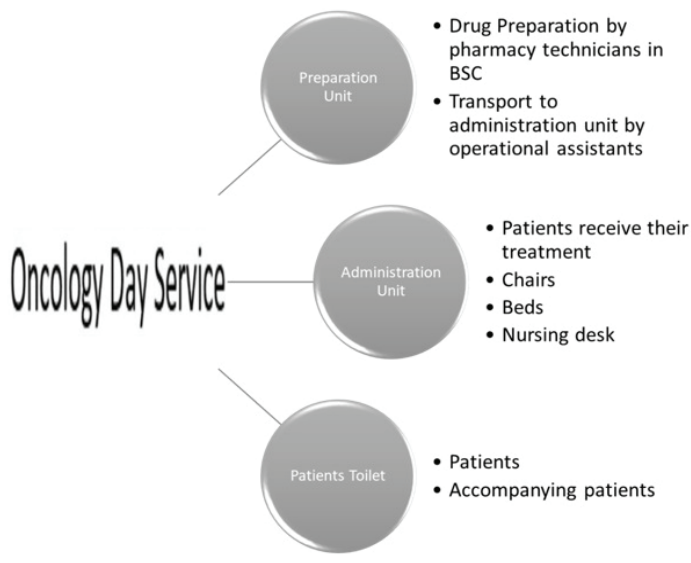

Figure 1 The three units sampled in the ODS

The drug preparation and administration surfaces are cleaned at the end of the working day. The toilet is cleaned several times a day and more thoroughly at the end of the day. The cleaning products used were the same as in other hospital facilities For the surfaces the staff used a product containing sodium tripolyphosphate (2.5-10\%), sulphonic acid $(<2.5 \%)$, sodium lauryl ether sulphate $(2.5-10 \%)$, propan-2-ol (2.5-10\%), and a small percentage of alcohol. For patient toilet they used a product with sodium hypochlorite $(<5 \%)$.

\section{Sampling}

The choice of surfaces or objects to be wiped for samples was based on the observed everyday activities at the ODS and included surfaces and objects likely to be contaminated with cytotoxic drugs either through work or other routine behaviour (33).

Each spot was sampled twice: in the morning before drug handling started and three hours after it started. In total we collected 59 samples. Of the 29 morning samples, 12 were taken from the preparation unit, 12 from the administration unit, and five from the patient toilet. Three hours into the drug handling, we took 30 more samples: 12 from the preparation unit, 13 from the administration unit, and five from the toilet.

Samples were taken with a $100 \mathrm{~cm}^{2}$ Kimtech Science wipe (Kimberly-Clark Professional, Roswell, GA, USA) soaked in ethyl-acetate and fastened to a stainless steel frame $\left(100 \mathrm{~cm}^{2}\right)$, as described elsewhere (33), except for door handles, computer mice, and telephones, where we could not use the stainless frame for obvious reasons. The wipes were then placed in Petri dishes, sealed with Parafilm $\mathrm{M}^{\circledR}$ (Bemis, Neenah, WI, USA), stored at $2-8{ }^{\circ} \mathrm{C}$ for transport to the laboratory in Lisbon $(3 \mathrm{~h})$, and then frozen at $-20{ }^{\circ} \mathrm{C}$ up to two months until analysis.

The frame was cleaned between each sampling, and a new pair of gloves was used for each new wipe. All wipe samples were collected by the same person to ensure reliable and similar sampling. Blank wipes were used to check that 
no contamination occurred during sampling and transportation to the laboratory.

\section{Sample analysis}

The samples were analysed for cyclophosphamide (CP), 5-fluorouracil (5-FU), and paclitaxel (PTX) as the most commonly and abundantly used drugs in our ODS and in most of the oncology settings. Testing for all cytotoxic drugs would be too cost-ineffective $(31,32,40-44)$.

The wipes were placed in $15-\mathrm{mL}$ capped tubes with $10 \mathrm{~mL}$ of mobile phase (see below) for extraction in a roll homogeniser for 10 minutes.

The extracts were then forced through a $0.2 \mu \mathrm{m}$ filter and injected in a high-performance liquid chromatographer with a diode array detector (HPLC-DAD) for separation and quantification with a Thermo Unicam Surveyor (Thermo Scientific ${ }^{\mathrm{TM}}$, San José, CA, USA). To do that we used the C18 Hypersil-GOLD ${ }^{\circledR}$ (Thermo Scientific ${ }^{\mathrm{TM}}$ ) $15 \times 5 \times 4.6$, a respective guard column, and acetonitrile:methanol:water $(19: 13: 68)$ as mobile phase. The flow rate was $0.8 \mathrm{~mL} \mathrm{~min}^{-1}$. All the HPLC-grade solvents used were purchased from VWR International (Radnor, PA, USA). CP, 5-FU, and PTX for calibration were purchased from Merck KGaA (Darmstadt, Germany). Calibration curves were obtained after their extraction from spiked wipes. Each sample was injected in triplicate. Chromatograms were integrated with the Xcalibur ${ }^{\mathrm{TM}} 2.0$ software (Thermo Scientific ${ }^{\mathrm{TM}}$ ).

\section{Method validation}

Validation followed the US Food and Drug Administration regulatory guidelines for analytical procedures (57). Table 1 shows the results of method validation, including the limit of detection (LOD) and limit of quantification (LOQ), which were within the range for this method (66-68). A sample was considered positive for a particular drug if the value was above LOD.

All calibration curves with a correlation coefficient $\left(\mathrm{R}^{2}\right)$ greater than 0.990 for the three drugs were linear over the range. The LOD and LOQ correspond to the mean of five calibration curves.

Tables 2, 3, and 4 show the intra- and inter-day accuracy and precision parameters at six calibration levels. Table 5 summarises recoveries of 5-FU, CP, and PTX.

Their retention time was about 3.9, 5.8, and 18.4 minutes, respectively. Their typical chromatograms were well resolved, which indicates that the assay was selective (Figure 2).

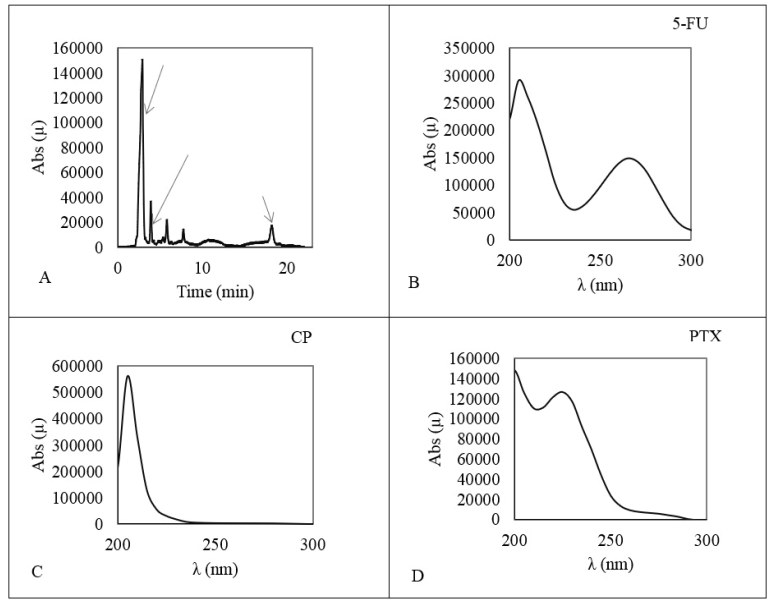

Figure 2 Typical chromatogram of a wipe spiked with the drugs under study A: all three drugs; $B, C$, and $D$ : absorption spectra

\section{Statistical analysis}

Normality of distribution was tested with the ShapiroWilk test. Prevalence of contamination before and after drug handling was compared with the frequency analysis. To compare drug concentrations at both time points (before and after drug handling started) between the three locations (drug preparation unit, drug administration unit, and patient toilet) we used the Kruskal-Wallis test. Kruskal-Wallis multiple comparison was also used for significantly different results. To compare 5-FU, CP, and PTX concentrations between the two time points we used the Wilcoxon test. The level of significance was set at a $5 \%$.

\section{RESULTS}

Table 6 shows the distribution of positive samples with quantifiable drugs (>LOQ) by sampling time. Of the 29 morning samples 21 were contaminated: seven in the preparation unit, 10 in the drug administration unit, and four in patient toilet (Table 7). Of these, three were contaminated with more than one drug:, two in the drug administration unit, and one in the patient toilet.

Of the 30 samples collected three hours into the drug handling, 24 were positive, 19 of which from the drug preparation and administration units and 5 from the patient toilet (Table 8). Of these, five were contaminated with more than one drug: four in the preparation unit, and one in the drug administration unit.

Table 9 shows total contamination of each unit by drug.

Table 1 Method validation for each cytotoxic drug according to the FDA regulatory guidelines for analytical procedures (57)

\begin{tabular}{lccccc} 
& Equation & R2 & LOD & LLOQ & Range \\
\hline 5-FU & Peak area $=35209+16473.8 \times 5-F U$ & 0.9983 & $0.900 \mathrm{ng}$ & $2.728 \mathrm{ng}$ & LOD-75 ng \\
\hline CP & Peak area=35230.8+25147.7xCP & 0.9936 & $1.78 \mu \mathrm{g}$ & $5.40 \mu \mathrm{g}$ & LOD-60 $\mu \mathrm{g}$ \\
\hline PTX & Peak area=21507.4+147442xPTX & 0.9923 & $0.20 \mathrm{ng}$ & $061 \mathrm{ng}$ & LOD-16.65 ng \\
\hline
\end{tabular}


Table 2 HPLC intra-day and inter-day (n=5) quantification accuracy and precision for 5-fluorouracil (injection volume $100 \mu \mathrm{L}$ )

\begin{tabular}{ccccc}
\hline $\begin{array}{c}\text { Nominal amount } \\
(\mathbf{n g})\end{array}$ & $\begin{array}{c}\text { Measured amount } \\
(\mathbf{n g})\end{array}$ & SD & $\begin{array}{c}\text { Precision } \\
(\% \text { RSD })\end{array}$ & $\begin{array}{c}\text { Accuracy } \\
(\%)\end{array}$ \\
\hline 7.500 & 6.950 & 0.49 & 7.10 & -7.33 \\
\hline 15.000 & 15.300 & 0.09 & 0.60 & 2.00 \\
\hline 30.000 & 30.840 & 0.08 & 0.27 & 2.80 \\
\hline 45.000 & 44.360 & 0.89 & 2.00 & -1.42 \\
\hline 60.000 & 60.050 & 1.23 & 2.05 & 0.08 \\
\hline 75.000 & 72.270 & 1.67 & 2.31 & -3.64 \\
\hline & Inter-day & & \\
\hline 7.500 & 7.050 & 0.18 & 2.56 & -6.00 \\
\hline 15.000 & 15.100 & 0.21 & 1.41 & 0.67 \\
\hline 30.000 & 29.840 & 0.45 & 1.50 & -0.53 \\
\hline 45.000 & 45.380 & 0.53 & 1.16 & 0.84 \\
\hline 60.000 & 58.550 & 0.24 & 0.41 & -2.42 \\
\hline 75.000 & 76.270 & 0.28 & 0.37 & 1.69 \\
\hline
\end{tabular}

Of the total fifty nine samples collected, 45 were contaminated with one or more drugs. Considering only the results higher than the LOQ, contamination before and during drug handling did not differ significantly $(\mathrm{p}>0.05)$ in any of the three units. However, the units did differ in contamination with $\mathrm{CP}$ and 5-FU. CP was significantly higher in the preparation unit than in other units three hours into the drug handling, and significantly higher in the administration unit than the others before drug handling (Figure 3). In turn, 5-FU was significantly higher in the preparation unit and the patient toilet three hours into the drug handling, while in the administration unit the concentration was higher before (Figure 4). Contamination with PTX was not statistically analysed because there were too few quantifiable samples to compare.
Table 10 shows the three sampling spots with significantly higher contamination with any of the cytotoxic drugs compared to the rest.

\section{DISCUSSION}

Our results clearly show that the current cleaning procedure is ineffective in removing contamination with the three representative cytotoxic drugs. They also suggest that other variables contributed to contamination as well.

Our findings are similar to the contamination reported in Portuguese hospitals (33), but we did not expect to find higher contamination in the drug administration unit than in the preparation unit, where drugs are handled and mixed in high concentrations $(33,34)$.

Table 3 HPLC intra-day and inter-day (n=5) quantification accuracy and precision for cyclophosphamide (injection volume $100 \mu \mathrm{L}$ )

\begin{tabular}{ccccc}
\hline $\begin{array}{c}\text { Nominal amount } \\
(\boldsymbol{\mu g})\end{array}$ & $\begin{array}{c}\text { Measured amount } \\
(\boldsymbol{\mu g})\end{array}$ & SD & $\begin{array}{c}\text { Precision } \\
(\mathbf{\%} \text { RSD })\end{array}$ & $\begin{array}{c}\text { Accuracy } \\
(\boldsymbol{\%})\end{array}$ \\
\hline 6.000 & Intra-day & & & \\
\hline 12.000 & 5.300 & 0.36 & 6.7 & -11.7 \\
\hline 24.000 & 12.300 & 0.43 & 3.5 & 2.5 \\
\hline 36.000 & 25.160 & 0.55 & 2.2 & 4.8 \\
\hline 48.000 & 35.240 & 0.74 & 2.1 & -2.1 \\
\hline 60.000 & 44.230 & 0.75 & 1.7 & -7.9 \\
\hline & 51.000 & 1.79 & 3.5 & -15.0 \\
\hline 6.000 & Inter-day & & \\
\hline 12.000 & 5.50 & 0.28 & 5.14 & 0.4 \\
\hline 24.000 & 12.02 & 0.53 & 4.4 & -8.3 \\
\hline 36.000 & 23.70 & 0.88 & 3.7 & 0.2 \\
\hline 48.000 & 36.0 & 2.20 & 6.1 & -1.3 \\
\hline 60.000 & 48.2 & 2.31 & 4.8 & 0.0 \\
\hline & 58.896 & 3.53 & 6.0 & 0.4 \\
\hline
\end{tabular}




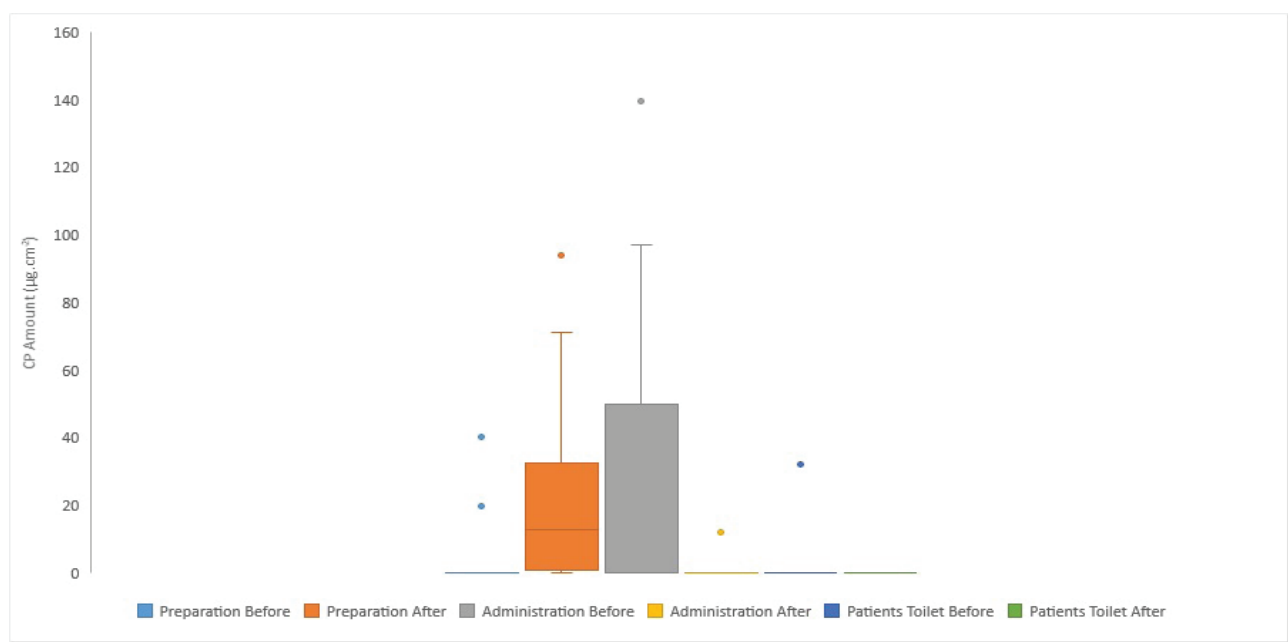

Figure 3 CP contamination $\left(\mu \mathrm{g} \mathrm{cm}^{-2}\right.$ ) before and after drug handling started in each unit

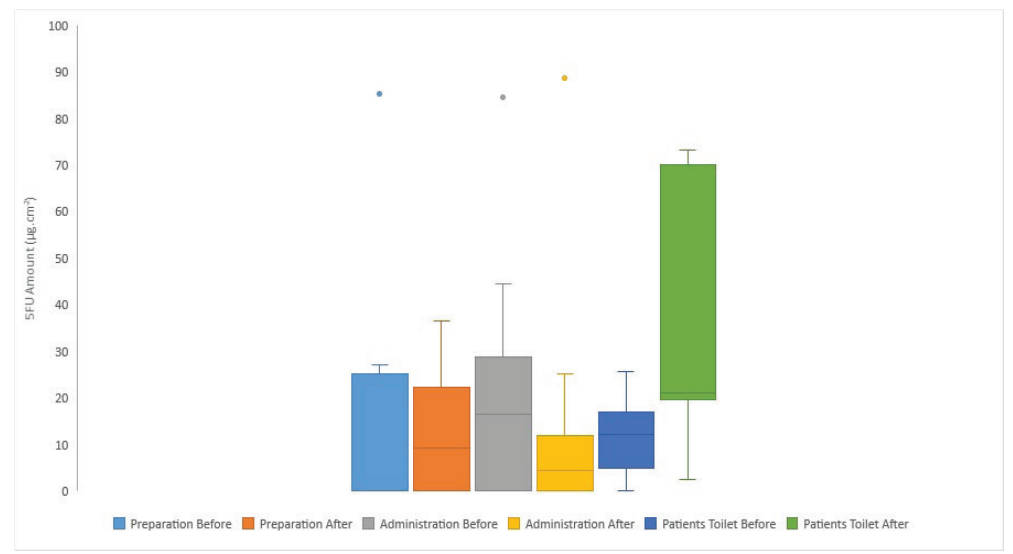

Figure 4 5-FU contamination ( $\mathrm{ng} \mathrm{cm}^{-2}$ ) before and after drug handling started in each unit

In the preparation unit the most contaminated surfaces before drug handling were the ones in the support room and three hours into the handling, the most contaminated surfaces were the ones in the clean room (Table 7), which is quite expected as handling goes. Clean rooms are the central points for drug preparation but are also more thoroughly cleaned than other rooms when handling is over. This probably explains the distribution of contaminated surfaces at both sampling times in both units (Figures 2 and 3 and Table 10). Similar findings were reported by FleurySouverain et al. (30) for samples collected after the handling started, as they did not collect samples after cleaning.

In our study, 5-FU was found in most samples at both sampling time points, which confirms the findings reported by Kiffmeyer et al. (24). They also reported that 5-FU was the most used drug, which may explain our findings as well.

In both of our units and the patient toilet the most contaminated surfaces were the ones handled without gloves (phones, computer mouse, bed in the treatment room, toilet light switch, flush handle, and handlebars) regardless of the sampling time point. The same was reported in our previous study (33), where we attributed contamination to inappropriate cleaning and drug handling procedures. The same pattern was observed in a study of Italian hospitals (41), which reported that workers did not remove gloves immediately after drug handling, and therefore spread the contamination on phones, chairs, closets and other surfaces not directly involved in drug preparation and administration. The same conclusions were reported by Kiffmeyer et al. (24), who found high concentrations of 5-FU on a closet door knob that was not used to store 5-FU.

Contamination of infusion pumps after drug administration started is similar to earlier reports $(19,33$, 42). In fact, Hon et al. (34) claim that infusion pumps are most often touched by nurses during drug administration. This is of particular concern, because we found contamination before and after drug administration and also observed that the pumps were sometimes handled without gloves. Clearly, this equipment is not being cleaned.

We would also like to draw attention to the contamination of the beds in the treatment room, bed chart holders in particular. We observed that this surface was handled/ touched by nurses and patients' families, implicating exposure for all these persons. This is one more surface that probably is not being cleaned well or often enough.

Furthermore, a study of health and safety practices by nurses that administered cytotoxic drugs in 2011 reported that $12 \%$ of the 2069 respondents failed to use gloves, even though $4 \%$ reported skin contact with the drug during handling and administration (44). 
Table 4 HPLC intra-day and inter-day (n=5) quantification accuracy and precision for paclitaxel (injection volume $100 \mu L$ )

\begin{tabular}{ccccc}
\hline $\begin{array}{c}\text { Nominal amount } \\
(\mathbf{n g})\end{array}$ & $\begin{array}{c}\text { Measured amount } \\
(\mathbf{n g})\end{array}$ & SD & $\begin{array}{c}\text { Precision } \\
(\% \text { RSD) }\end{array}$ & $\begin{array}{c}\text { Accuracy } \\
(\mathbf{\%})\end{array}$ \\
\hline 1.665 & 1.812 & 0.395 & 21.811 & 8.80 \\
\hline 3.330 & 3.014 & 0.182 & 6.035 & -9.50 \\
\hline 6.660 & 6.554 & 0.474 & 7.230 & -1.60 \\
\hline 9.990 & 10.212 & 0.266 & 2.601 & 2.22 \\
\hline 13.320 & 13.800 & 0.447 & 3.243 & 3.60 \\
\hline 16.650 & 16.220 & 0.448 & 2.763 & -2.58 \\
\hline \multicolumn{5}{c}{ Intra-day } \\
\hline 1.665 & 1.730 & 0.07 & 4.15 & 3.9 \\
\hline 3.330 & 3.12 & 0.17 & 5.35 & -6.3 \\
\hline 6.660 & 6.450 & 0.26 & 4.1 & -3.2 \\
\hline 9.990 & 10.20 & 0.62 & 6.1 & 2.1 \\
\hline 13.320 & 13.700 & 0.86 & 6.3 & 2.9 \\
\hline 16.650 & 16.320 & 1.15 & 7.02 & -2.0 \\
\hline
\end{tabular}

We also have to draw attention to the widespread contamination of the patient toilet before and after drug handling started, as it puts family members at risk of exposure, making this a public health issue as well. These findings raise particular concern, because Moretti et al. (13) showed in a recent study that handling cytotoxic drugs, even under controlled conditions, involves a considerable genotoxic risk (13).

What explains much of the contamination found in our study is that our ODS had only a biological safety cabinet, located in the clean room, but not a closed-system drug transfer device. By default, biological safety cabinets are heavily contaminated and are difficult to clean, and so are the objects taken out of the cabinet (45). Closed-system drug transfer devices serve to prevent transfer of contamination from these objects to outside surfaces (4). The benefits of closed drug transfer systems have already been demonstrated by Sessink et al. (46) and Simon et al. (47), but the latter also noted that the device could not completely prevent chemical contamination.

\section{Cleaning issues and recommendations}

The recent EU recommendations (4) identify cleaning as critical in reducing the spread of contamination. Cleaning can reduce most of the contamination, but not all of it, because there is no universal agent for different chemical structures of cytotoxic drugs.

Several authors have tried to find a an agent capable of inactivating, degrading, and reducing contamination with cytotoxic drugs in oncology services (48-55), but the issue remains. Our study only confirms that, as we found contamination even on supposedly cleaned surfaces before drug handling began.

Assessing the efficacy of the cleaning methods usually employed in their healthcare facility to eliminate environmental contamination with $\mathrm{CP}$, Touzin et al. (55) recommended combining sodium hypochlorite and sodium thiosulfate to obtain optimal results. However, this and many other studies address decontamination of a single cytotoxic agent $(48,55-57)$, while in reality surfaces are often contaminated with several agents. Lamerie et al. (52) therefore assessed the efficiency of several chemical solutions to decontaminate two types of work surfaces intentionally contaminated with ten cytotoxic drugs. Sodium hypochlorite showed the highest overall efficiency of $98 \%$. Promising were also solutions containing anionic surfactants with a high efficiency to safety ratio, as they bind to impurities and particles that are suspended in the liquid, which makes them effective cleaning agents in water. In fact, the EU report (4) clearly points out that no single chemical can completely clean, disinfect, and decontaminate surfaces contaminated with cytotoxic drugs.

The cleaning product used in our ODS was the same as the ones used in other hospital facilities not handling cytotoxic agents. This suggests that there are no set criteria to select a cleaning product that would be specific for an ODS and effective enough to warrant chemical

Table 5 Recovery of the cytotoxic drugs from spiked wipes ( $n=3$ )

\begin{tabular}{ccc}
\hline \multirow{2}{*}{ Drug } & $\begin{array}{c}\text { Nominal } \\
\text { amount }\end{array}$ & $\begin{array}{c}\text { Recovery } \\
(\%)\end{array}$ \\
\cline { 2 - 3 } 5-FU (ng) & 15 & 95.80 \\
\cline { 2 - 3 } & 45 & 86.30 \\
\hline \multirow{2}{*}{ CP $(\mu \mathrm{g})$} & 75 & 91.03 \\
\cline { 2 - 3 } & 12 & 93.43 \\
\hline & 36 & 96.55 \\
\hline PTX $(\mathrm{ng})$ & 3.33 & 95.32 \\
\hline & 9.99 & 80.85 \\
\hline
\end{tabular}


Table 6 Samples with values $>L O Q$

\begin{tabular}{lcccccc}
\hline & $\begin{array}{c}\text { Sampling before } \\
(\mathbf{n = 2 9})\end{array}$ & \multicolumn{3}{c}{$\begin{array}{c}\text { Sampling after } \\
(\mathbf{n = 3 0})\end{array}$} \\
\hline Drugs & $\begin{array}{c}\mathrm{CP} \\
\left(\mu \mathrm{g} \mathrm{cm}^{-2}\right)\end{array}$ & $\begin{array}{c}5-\mathrm{FU} \\
\left(\mathrm{ng} \mathrm{cm}^{-2}\right)\end{array}$ & $\begin{array}{c}\text { PTX } \\
\left(\mathrm{ng} \mathrm{cm}^{-2}\right)\end{array}$ & $\begin{array}{c}\mathrm{CP} \\
\left(\mu \mathrm{g} \mathrm{cm}^{-2}\right)\end{array}$ & $\begin{array}{c}5-\mathrm{FU} \\
\left(\mathrm{ng} \mathrm{cm}^{-2}\right)\end{array}$ & $\begin{array}{c}\text { PTX } \\
\left(\mathrm{ng} \mathrm{cm}^{-2}\right)\end{array}$ \\
\hline Positive samples & 7 & 16 & 2 & 10 & 20 & 0 \\
\hline $\begin{array}{l}\text { Mean } \\
\text { Range }\end{array}$ & 16.5 & 17 & 0.24 & 2.0 & 19.0 & $<$ LOQ \\
\hline
\end{tabular}

Table 7 Surface contamination levels by each drug before handling $(n=29)$

\begin{tabular}{|c|c|c|c|c|c|c|}
\hline \multirow{2}{*}{ Unit } & \multirow{2}{*}{ Surfaces } & \multicolumn{5}{|c|}{ Drug } \\
\hline & & $\begin{array}{l}\text { Specific } \\
\text { surfaces }\end{array}$ & $\begin{array}{c}\mathrm{CP} \\
\left(\mu \mathrm{g} \mathrm{cm}^{-2}\right)\end{array}$ & $\begin{array}{l}\text { Specific } \\
\text { surfaces }\end{array}$ & $\begin{array}{c}5-F U \\
\left(n g ~ ~ c m^{-2}\right)\end{array}$ & $\begin{array}{c}\text { PTX } \\
\left(\mathrm{ng} \mathrm{cm}^{-2}\right)\end{array}$ \\
\hline \multirow{12}{*}{ 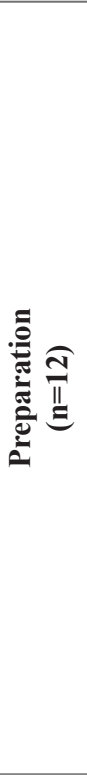 } & $\begin{array}{c}\text { Clean room - biological safety cabinet (BSC) } \\
\text { chair }\end{array}$ & & 0 & & 0 & 1.98 \\
\hline & Clean room - pass through handle & & 0 & & 24.48 & 0 \\
\hline & Clean room - support table & & 0 & & 0 & 0 \\
\hline & Clean room - front barrier grating of the BSC & & 0 & & 0 & 0 \\
\hline & Clean room - handle of the BSC protection & & 0 & & 0 & 0 \\
\hline & $\begin{array}{l}\text { Support room - table receiving finished } \\
\text { preparations }\end{array}$ & & 40.18 & & 0 & 0 \\
\hline & $\begin{array}{c}\text { Support room - table where preparations done } \\
\text { are registered }\end{array}$ & & 19.83 & & 0 & 0 \\
\hline & Support room - box for manual transportation & & 0 & & 0 & 0 \\
\hline & $\begin{array}{c}\text { Support room - pass through handle and } \\
\text { interior }\end{array}$ & & 0 & & 0 & $<\mathrm{LOQ}$ \\
\hline & Support room - computer mouse & & 0 & & 27.18 & 0 \\
\hline & Support room - phone & & 0 & & 85.35 & $<\mathrm{LOQ}$ \\
\hline & $\begin{array}{l}\text { Support room - drug storage cabinet - } \\
\text { handles and interior }\end{array}$ & & 0 & & 27 & 0 \\
\hline \multirow{12}{*}{ 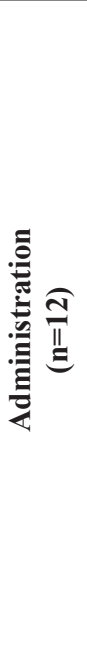 } & Infusion pump holder & & 58.85 & & 0 & 0 \\
\hline & Pass through handle & & 97.05 & & 21 & 0 \\
\hline & Table that receives drug preparations & & 0 & & 0 & 0 \\
\hline & Computer mouse & & 0 & & 44.4 & 0 \\
\hline & Table for preparing other medication & & 0 & & 11.93 & 0 \\
\hline & Treatment chairs - armrests & & 0 & & $<\mathrm{LOQ}$ & 0 \\
\hline & Trolley worktop & & 41.32 & & 0 & 0 \\
\hline & \multirow{2}{*}{$\begin{array}{l}\text { Treatment room - bed chart holder, infusion } \\
\text { pump holder, and chair armrest }\end{array}$} & \multirow[b]{2}{*}{ Bed } & \multirow[b]{2}{*}{139.55} & Bed & 26.6 & \multirow[b]{2}{*}{0} \\
\hline & & & & $\begin{array}{l}\text { Chair } \\
\text { armrest }\end{array}$ & 4.28 & \\
\hline & \multirow{3}{*}{ Nurse desk - phone, desk, chair } & & \multirow{3}{*}{0} & Phone & 84.69 & \multirow{3}{*}{0} \\
\hline & & & & Table & 22.81 & \\
\hline & & & & Chair & 35.67 & \\
\hline \multirow{5}{*}{ 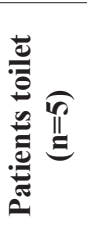 } & Door handles & & 0 & & 17 & 0 \\
\hline & Light switch & & 32.01 & & 25.76 & 0 \\
\hline & Flush handle & & 0 & & 12.04 & 3.67 \\
\hline & Arm support & & 0 & & 4.99 & 0 \\
\hline & Water tap & & 0 & & 0 & 0 \\
\hline
\end{tabular}


Table 8 Surface contamination level by each drug after the beginning of tasks ( $n=30)$

\begin{tabular}{|c|c|c|c|c|c|c|}
\hline \multirow[b]{2}{*}{ Unit } & \multirow[b]{2}{*}{ Surfaces } & \multicolumn{5}{|c|}{ Drug } \\
\hline & & $\begin{array}{c}\mathbf{C P} \\
\left(\mu \mathrm{g} \mathrm{cm}^{-2}\right)\end{array}$ & $\begin{array}{l}\text { Specific } \\
\text { surfaces }\end{array}$ & $\begin{array}{c}\text { 5-FU } \\
\left(\mathrm{ng} \mathrm{cm}^{-2}\right)\end{array}$ & $\begin{array}{l}\text { Specific } \\
\text { surfaces }\end{array}$ & $\underset{\left(\mathrm{ng} \mathrm{cm}^{-2}\right)}{\text { PTX }}$ \\
\hline \multirow{12}{*}{ 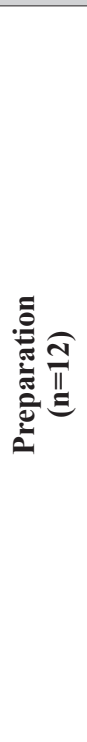 } & $\begin{array}{c}\text { Clean room - biological safety cabinet (BSC) } \\
\text { chair }\end{array}$ & 93.92 & & 31.75 & & $<\mathrm{LOD}$ \\
\hline & Clean room - pass through handle (sample 1) & 18.9 & & & & \\
\hline & Clean room - pass through handle (sample 2) & 71.32 & & 16.6 & & $<\mathrm{LOD}$ \\
\hline & Clean room - support table & $<$ LOD & & $<$ LOD & & $<\mathrm{LOD}$ \\
\hline & Clean room - front barrier grating of the BSC & 45.99 & & $<\mathrm{LOD}$ & & $<\mathrm{LOD}$ \\
\hline & Clean room - handle of the BSC protection & $<$ LOD & & 18.8 & & $<\mathrm{LOD}$ \\
\hline & $\begin{array}{l}\text { Support room - table receiving finished } \\
\text { preparations }\end{array}$ & 12.27 & & $<\mathrm{LOD}$ & & $<\mathrm{LOD}$ \\
\hline & $\begin{array}{l}\text { Support room - table where preparations } \\
\text { done are registered }\end{array}$ & $<$ LOD & & 1.86 & & $<\mathrm{LOD}$ \\
\hline & $\begin{array}{c}\text { Support room - Pass through handle and } \\
\text { interior }\end{array}$ & 2 & & $<\mathrm{LOD}$ & & $<\mathrm{LOD}$ \\
\hline & Support room - computer mouse & 12.81 & & 36.49 & & $<$ LOD \\
\hline & Support room - phone & 13.03 & & 23.52 & & $<$ LOD \\
\hline & $\begin{array}{l}\text { Support room - drug storage cabinet - } \\
\text { handles and interior }\end{array}$ & $<\mathrm{LOD}$ & Handle & 4.61 & & $<\mathrm{LOD}$ \\
\hline \multirow{13}{*}{ 莺 } & Infusion pumps holder and pump & $<\mathrm{LOD}$ & Pump & 25.21 & & $<$ LOD \\
\hline & Transfer interior and handle & $<\mathrm{LOD}$ & Handle & $<\mathrm{LOQ}$ & & $<$ LOD \\
\hline & Table that receives drug preparations & $<\mathrm{LOD}$ & & $<\mathrm{LOD}$ & & $<$ LOD \\
\hline & Computer mouse & 13.15 & & 17 & & $<\mathrm{LOD}$ \\
\hline & Table for preparing other type of medication & $<$ LOD & & $<\mathrm{LOD}$ & & $<\mathrm{LOD}$ \\
\hline & Treatment chairs - armrests & $<\mathrm{LOD}$ & & 2.32 & & $<\mathrm{LOD}$ \\
\hline & Trolley worktop & $<\mathrm{LOD}$ & & $<\mathrm{LOD}$ & & $<\mathrm{LOD}$ \\
\hline & Catheters room - table & 11.98 & & $<$ LOD & & $0<\mathrm{LOD}$ \\
\hline & \multirow[b]{2}{*}{$\begin{array}{l}\text { Treatment room - bed chart holder, infusion } \\
\text { pump holder, and chair armrest }\end{array}$} & \multirow[b]{2}{*}{$<\mathrm{LOD}$} & Bed & 12.44 & \multirow[b]{2}{*}{ Bed } & \multirow[b]{2}{*}{$<\mathrm{LOQ}$} \\
\hline & & & $\begin{array}{c}\text { Infusion } \\
\text { pump holder }\end{array}$ & 8.85 & & \\
\hline & \multirow{3}{*}{ Nurse desk - phone } & \multirow{3}{*}{$<\mathrm{LOD}$} & Phone & 88.72 & \multirow{3}{*}{ Phone } & \multirow{3}{*}{$<\mathrm{LOQ}$} \\
\hline & & & Table & 4.33 & & \\
\hline & & & Chair & 10.43 & & \\
\hline \multirow{5}{*}{ 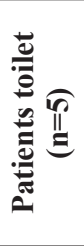 } & Door handles & $<\mathrm{LOD}$ & & 21 & & $<\mathrm{LOQ}$ \\
\hline & Light switch & $<\mathrm{LOD}$ & & 2.57 & & $<\mathrm{LOD}$ \\
\hline & Flush handle & $<$ LOD & & 19.73 & & $<$ LOD \\
\hline & Arm support & $<\mathrm{LOD}$ & & 70.03 & & $<\mathrm{LOD}$ \\
\hline & Water tap & $<\mathrm{LOD}$ & & 73.32 & & $<\mathrm{LOD}$ \\
\hline
\end{tabular}

decontamination of the surfaces. The cleaning product used in our ODS contained sodium tripolyphosphate, sulphonic acid, sodium lauryl ether sulphate, propan-2-ol, and a small percentage of alcohol. The toilet was cleaned with a product containing sodium hypochlorite instead. However, despite the use of sodium hypochlorite, almost all toilet samples showed contamination. This points to other factors that may render decontamination less efficient, such as dilution and the agent contact time with the surface (55).
However, we also believe the criteria used to select which surfaces to clean affected the findings reported by this and previous studies. They are focused on rendering the surfaces aseptic by removing microorganisms, because oncology patients are most often immunocompromised. Accordingly, the cleaning solutions are selected based on their disinfection efficacy and not on chemical decontamination. 
Table 9 Total contamination for each unit by drug

\begin{tabular}{|c|c|c|c|c|c|c|c|c|c|}
\hline & \multicolumn{3}{|c|}{ Preparation } & \multicolumn{3}{|c|}{ Administration } & \multicolumn{3}{|c|}{ Toilets } \\
\hline Drugs & $\begin{array}{c}\mathrm{CP} \\
\left(\mu \mathrm{g} \mathrm{cm}^{-2}\right)\end{array}$ & $\begin{array}{c}5-\mathrm{FU} \\
\left(\mathrm{ng} \mathrm{cm}^{-2}\right)\end{array}$ & $\begin{array}{c}\text { PTX } \\
\left(\mathrm{ng} \mathrm{cm}^{-2}\right)\end{array}$ & $\begin{array}{c}\mathrm{CP} \\
\left(\mu \mathrm{g} \mathrm{cm}^{-2}\right)\end{array}$ & $\begin{array}{c}5-\mathrm{FU} \\
\left(\mathrm{ng} \mathrm{cm}^{-2}\right)\end{array}$ & $\begin{array}{c}\text { PTX } \\
\left(\mathrm{ng} \mathrm{cm}^{-2}\right)\end{array}$ & $\begin{array}{c}\mathrm{CP} \\
\left(\mu \mathrm{g} \mathrm{cm}^{-2}\right)\end{array}$ & $\begin{array}{c}5-\mathrm{FU} \\
\left(\mathrm{ng} \mathrm{cm}^{-2}\right)\end{array}$ & $\begin{array}{c}\text { PTX } \\
\left(\mathrm{ng} \mathrm{cm}^{-2}\right)\end{array}$ \\
\hline $\begin{array}{l}\text { Before drug } \\
\text { handling }\end{array}$ & 60.0 & 164.0 & 1.98 & 336.77 & 251.38 & 0 & 32.01 & 59.79 & 3.67 \\
\hline $\begin{array}{l}\text { Three hours } \\
\text { into drug } \\
\text { handling }\end{array}$ & 270.24 & 133.63 & ----- & 25.13 & 169.3 & ----- & 0 & 186.65 & ----- \\
\hline Total & 330.24 & 297.63 & 1.98 & 361.9 & 420.68 & ----- & 32.01 & 246.44 & 3.67 \\
\hline
\end{tabular}

Table 10 Surfaces with higher contamination

\begin{tabular}{|c|c|c|c|}
\hline Sampling time & Preparation & Administration & Patients toilet \\
\hline $\begin{array}{l}\text { Before handling } \\
\text { drugs }\end{array}$ & $\begin{array}{c}\text { Table that receives drug preparations, } \\
\text { Phone in the preparation support room, } \\
\text { Pass through handle }\end{array}$ & $\begin{array}{l}\text { Pass through handle, bed in the } \\
\text { treatment room, phone on the } \\
\text { nursing desk }\end{array}$ & $\begin{array}{l}\text { Light switch, flush, } \\
\text { and arms support }\end{array}$ \\
\hline $\begin{array}{l}\text { Three hours into } \\
\text { drug handling }\end{array}$ & $\begin{array}{l}\text { Chair of the BSC, PC mouse in the prepa- } \\
\text { ration support room, pass through handle }\end{array}$ & $\begin{array}{l}\text { Infusion pump, computer mouse, } \\
\text { phone on the nursing desk }\end{array}$ & $\begin{array}{l}\text { Flush, arms sup- } \\
\text { port, water tap }\end{array}$ \\
\hline
\end{tabular}

Additionally, mainly the toilet floor was cleaned and not the surfaces touched by hand. This explains why all the toilet surfaces were contaminated before and after the drug handling started at the ODS.

\section{Surface monitoring recommendations}

This study stresses the importance of each oncology service having an effective monitoring programme in place. Monitoring should be frequent and collect reliable and detailed exposure information to identify the causes of contamination and appropriate measures to avoid or minimise exposure. Kiffmeyer et al. (24) reported a sustained contamination control thanks to one such regular monitoring programme. Furthermore, monitoring can show where cleaning has failed. Sampling should precede the implementation of preventive measures and be repeated once they are in place to establish their efficiency (60). Viegas et al. (64) demonstrated the usefulness of surface monitoring, as it not only gives an indirect measure of dermal exposure but also relevant guidelines to prevent further exposure.

Although this study findings call for changes in the workflow and cleaning that would reduce contamination and exposure to cytotoxic drugs, it has several limitations to bear in mind. One is the limited number of positive samples for PTX, even though it is the most used cytotoxic drug in this ODS. This points to the need to revise the sampling method and frequency. The other limitation is that we did not sample exactly the same surfaces before and three hours into the drug handling because some of the surfaces were covered by objects used in everyday operations and therefor inaccessible. For this reason we cannot reliably follow how contamination developed between the two sampling times.

\section{CONCLUSIONS}

Our results have shown a widespread contamination in the ODS even after it has been cleaned and call for improvements to define an optimise cleaning. This includes the selection of proper cleaning agents or combinations thereof, optimal dilution, and contact time with the surfaces. This can only be accomplished in collaboration with trained cleaners, who have been made aware of the risks of poor cleaning practices.

Operating procedures, including technical resources should also be improved to avoid or reduce the spread of contamination. A surface monitoring programme could greatly contribute to achieve that goal, as it can provide guidelines for improvement.

\section{Acknowledgements}

This study was developed with the support of Escola Superior de Tecnologia da Saúde de Lisboa, Instituto Politécnico de Lisboa. The authors would like to thank to Dr Xavier Guardino Sola for the important comments that greatly improved the manuscript.

\section{Conflicts of interest}

None to declare.

\section{REFERENCES}

1. Falck K, Gröhn P, Sorsa M, Vainio H, Heinonen E, Holsti LR. Mutagenicity in urine in nurses handling cytotoxic drugs. Lancet 1979;8128:1250-1. PMID: 87722

2. European Agency for Health and Safety at Work (EU-OSHA). Current and emerging occupational safety and health $(\mathrm{OSH})$ issues in the healthcare sector, including home and community care, 2014 [displayed 16 August 2018]. Available 
at https://osha.europa.eu/en/publications/reports/current-andemerging-occupational-safety-and-health-osh-issues-in-thehealthcare-sector-including-home-and-community-care/view

3. European Commission Directorate-General for Employment, Social Affairs (EC). Occupational health and safety risks in the healthcare sector - Guide to prevention and good practice, 2011 [displayed 16 August 2018]. Available at http://ec europa.eu/social/BlobServlet?docId=7167\&langId=en

4. European Parliament (EP). Preventing occupational exposure to cytotoxic and other hazardous drugs: European policy recommendations, 2016 [displayed 16 August 2018]. Available at http://www.europeanbiosafetynetwork.eu/wpcontent/uploads/2016/05/Exposure-to-Cytotoxic-Drugs Recommendation_DINA4_10-03-16.pdf

5. Besse JP, Latour JF, Garric J. Anticancer drugs in surface waters. What can we say about the occurrence and environmental significance of cytotoxic, cytostatic and endocrine therapy drugs? Environ Int 2012;39:73-86. doi: 10.1016/j.envint.2011.10.002

6. Deblonde T, Hartemann P. Environmental impact of medical prescriptions: assessing the risks and hazards of persistence, bioaccumulation and toxicity of pharmaceuticals. Public Health 2013;127:312-7. doi: 10.1016/j.puhe.2013.01.026

7. Gajski G, Gerić M, Domijan A-M, Garaj-Vrhovac V. Combined cyto/genotoxic activity of a selected antineoplastic drug mixture in human circulating blood cells. Chemosphere 2016;165:529-38. doi: 10.1016/j.chemosphere.2016.09.058

8. Kosjek T, Heath E. Occurrence, fate and determination of cytostatic pharmaceuticals in the environment. TrAC Trends Anal Chem 2011;30:1065-87. doi: 10.1016/j.trac.2011.04.007

9. Toolaram AP, Kümmerer K, Schneider M. Environmental risk assessment of anti-cancer drugs and their transformation products: a focus on their genotoxicity characterization-state of knowledge and short comings. Mutat Res-Rev Mutat 2014;760:18-35. doi: 10.1016/j.mrrev.2014.02.001

10. Zhang J, Chang VWC, Giannis A, Wang JY. Removal of cytostatic drugs from aquatic environment: a review. Sci Total Environ 2013;445-446:281-98. doi: 10.1016/j. scitotenv.2012.12.061

11. Zounkova R, Kovalova L, Blaha L, Dott W. Ecotoxicity and genotoxicity assessment of cytotoxic antineoplastic drugs and their metabolites. Chemosphere 2010;81:253-60. doi 10.1016/j.chemosphere.2010.06.029

12. Kopjar N, Milas I, Garaj-Vrhovac V, Gamulin M. Alkaline comet assay study with breast cancer patients: evaluation of baseline and chemotherapy-induced DNA damage in nontarget cells. Clin Exp Med 2006;6:177-90. doi: 10.1007/ s10238-006-0113-8

13. Moretti M, Grollino MG, Pavanello S, Bonfiglioli R, Villarini M, Appolloni M, Carrieri M, Sabatini L, Dominici L, Stronati L, Mastrangelo G, Barbieri A, Fatigoni C, Bartolucci GB, Ceretti E, Mussi F, Monarca S. Micronuclei and chromosome aberrations in subjects occupationally exposed to antineoplastic drugs: a multicentric approach. Int Arch Occ Env Hea 2015;88:683-95. doi: 10.1007/s00420-014-0993-y

14. Turci R, Minoia C, Sottani C, Coghi R, Severi P, Castriotta C, Del Bianco M, Imbriani M. Occupational exposure to antineoplastic drugs in seven Italian hospitals: The effect of quality assurance and adherence to guidelines. J Oncol Pharm Pract 2011;17:320-32. doi: 10.1177/1078155210381931

15. Yoshida J, Koda S, Nishida S, Yoshida T, Miyajima K, Kumagai S. Association between occupational exposure levels of antineoplastic drugs and work environment in five hospitals in Japan. J Oncol Pharm Pract 2011;17:29-38. doi: 10.1177/1078155210380485

16. Zhang X, Zheng Q, Lv L, An M, Zhang Y, Wei Y, Feng W. Evaluation of adverse health risks associated with antineoplastic drug exposure in nurses at two Chinese hospitals: the effects of implementing a pharmacy intravenous admixture service. Am J Ind Med 2016;59:264-73. doi: 10.1002/ajim.22553

17. Connor TH, Lawson CC, Polovich M, McDiarmid MA. Reproductive health risks associated with occupational exposures to antineoplastic drugs in health care settings: A review of the evidence. J Occup Environ Med 2014:56:90110. doi: 10.1097/JOM.0000000000000249

18. Fransman W, Roeleveld N, Peelen S, de Kort W, Kromhout $H$, Heederik D. Nurses with dermal exposure to antineoplastic drugs: Reproductive outcomes. Epidemiology 2007;18:1129. doi: 10.1097/01.ede.0000246827.44093.c1

19. Fransman W, Peelen S, Hilhorst S, Roeleveld N, Heederik $\mathrm{D}$, Kromhout H. A pooled analysis to study trends in exposure to antineoplastic drugs among nurses. Ann Occup Hyg 2007;51:231-9. doi: 10.1093/annhyg/mel081

20. McDiarmid MA, Oliver MS, Rogers B, Escalante C. Chromosome 5 and 7 abnormalities in oncology personnel handling anticancer drugs. J Occup Environ Med 2010;52:1028-34. doi: 10.1097/JOM.0b013e3181f73ae6

21. Rombaldi F, Cassini C, Salvador M, Saffi J, Erdtmann B. Occupational risk assessment of genotoxicity and oxidative stress in workers handling anti-neoplasic drugs during a working week. Mutagenesis 2009;24:143-8. doi: 10.1093/ mutage/gen060

22. Mahboob M, Rahman MF, Rekhadevi PV, Sailaja N, Balasubramanyam A, Prabhakar PV, Singh SP, Reddy UA, Rao GS, Grover P. Monitoring of oxidative stress in nurses occupationally exposed to antineoplastic drugs. Toxicol Int 2012;19:20-4. doi: 10.4103/0971-6580.94510

23. Connor TH. Hazardous anticancer drugs in health care: environmental exposure assessment. Ann NY Acad Sci 2006;1076:615-23. doi: 10.1196/annals.1371.021

24. Kiffmeyer TK, Tuerk J, Hahn M, Stuetzer H, Hadtstein C, Heinemann A, Eickmann U. Application and assessment of a regular environmental monitoring of the antineoplastic drug contamination level in pharmacies - the MEWIP project. Ann Occup Hyg 2013;57:444-55. doi: 10.1093/annhyg/mes081

25. Meijster T, Fransman W, Veldhof R, Kromhout H. Exposure to antineoplastic drugs outside the hospital environment. Ann Occup Hyg 2006;50:657-64. doi: 10.1093/annhyg/mel023

26. Sessink PJ, Bos RP. Drugs hazardous to healthcare workers. Evaluation of methods for monitoring occupational exposure to cytostatic drugs. Drug Safety 1999;20:347-59. PMID: 10230582

27. Turci R, Sottani C, Spagnoli G, Minoia C. Biological and environmental monitoring of hospital personnel exposed to antineoplastic agents: a review of analytical methods. J Chromatogr B 2003;789:169-209. doi: 10.1016/S15700232(03)00100-4

28. Minoia C, Turci R, Sottani C, Schiavi A, Perbellini L, Angeleri S, Draicchio F, Apostoli P. Application of high performance liquid chromatography/tandem mass spectrometry in the environmental and biological monitoring of health care personnel occupationally exposed to cyclophosphamide and ifosfamide. Rapid Commun Mass 
Spectrom 1998;12:1485-93. doi: 10.1002/(SICI)10970231(19981030)12:20<1485::AID-RCM333>3.0.CO;2-N

29. Connor TH, Anderson RW, Sessink PJ, Broadfield L, Power LA. Surface contamination with antineoplastic agents in six cancer treatment centers in Canada and the United States. Am J Health-Syst Ph 1999;56:1427-32. PMID: 10428450

30. Fleury-Souverain S, Mattiuzzo M, Mehl F, Nussbaumer S, Bouchoud L, Falaschi L, Gex-Fabry M, Rudaz S, Sadeghipour F, Bonnabry P. Evaluation of chemical contamination of surfaces during the preparation of chemotherapies in 24 hospital pharmacies. Eur J Hosp Pharm 2015;22:333-41. doi: 10.1136/ejhpharm-2014-000549

31. Hedmer M, Georgiadi A, Bremberg ER, Jönsson BA, Eksborg S. Surface contamination of cyclophosphamide packaging and surface contamination with antineoplastic drugs in a hospital pharmacy in Sweden. Ann Occup Hyg 2005;49:62937. doi: 10.1093/annhyg/mei042

32. Schmaus G, Schierl R, Funck S. Monitoring surface contamination by antineoplastic drugs using gas chromatography-mass spectrometry and voltammetry. Am J Health Syst Pharm 2002;59:956-61. PMID: 12040735

33. Viegas S, Pádua M, Veiga A, Carolino E, Gomes M. Antineoplastic drugs contamination of workplace surfaces in two Portuguese hospitals. Environ Monit Assess 2014;186:7807-18. doi: 10.1007/s10661-014-3969-1

34. Hon CY, Teschke K, Chua P, Venners S, Nakashima L. Occupational exposure to antineoplastic drugs: identification of job categories potentially exposed throughout the hospital medication system. Saf Health Work 2011;2:273-81. doi: 10.5491/SHAW.2011.2.3.273

35. Sessink PJ, Cerná M, Rössner P, Pastorková A, Bavarová H, Franková K, Anzion RB, Bos RP. Urinary cyclophosphamide excretion and chromosomal aberrations in peripheral blood lymphocytes after occupational exposure to antineoplastic agents. Mutat Res 1994;309:193-9. doi: 10.1016/00275107(94)90092-2

36. Sottani C, Rinaldi P, Leoni E, Poggi G, Teragni C, Delmonte A, Minoia C. Simultaneous determination of cyclophosphamide, ifosfamide, doxorubicin, epirubicin and daunorubicin in human urine using high-performance liquid chromatography/electrospray ionization tandem mass spectrometry: bioanalytical method validation. Rapid Commun Mass Spectrom 2008;22:2645-59. doi: 10.1002/ rem.3657

37. Sottani C, Porro B, Imbriani M, Minoia C. Occupational exposure to antineoplastic drugs in four Italian health care settings. Toxicol Lett 2011;213:107-15. doi: 10.1016/j. toxlet.2011.03.028

38. Schierl R, Böhlandt A, Nowak D. Guidance values for surface monitoring of antineoplastic drugs in German pharmacies. Ann Occup Hyg 2009;53:703-11. doi: 10.1093/annhyg/ mep050

39. Sessink PJM, Connor TH, Jorgenson JA, Tyler TG. Reduction in surface contamination with antineoplastic drugs in 22 hospital pharmacies in the US following implementation of a closed-system drug transfer device. J Oncol Pharm Pract 2011;17:39-48. doi: 10.1177/1078155210361431

40. Touzin K, Bussières JF, Langlois E, Lefebvre M. Evaluation of surface contamination in a hospital hematology-oncology pharmacy. J Oncol Pharm Pract 2009;15:53-61. doi: $10.1177 / 1078155208096904$
41. Castiglia L, Miraglia N, Pieri M, Simonelli A, Basilicata P, Genovese G, Guadagni R, Acampora A, Sannolo N, Scafarto MV. Evaluation of occupational exposure to antiblastic drugs in an Italian hospital oncological department. J Occup Health 2008;50:48-56. PMID: 18285644

42. Kopp B, Schierl R, Nowak D. Evaluation of working practices and surface contamination with antineoplastic drugs in outpatient oncology health care settings. Int Arch Occup Environ Health 2013;86:47-55. doi: 10.1007/s00420-0120742-Z

43. Larson RR, Khazaeli MB, Dillon HK. Monitoring method for surface contamination caused by selected antineoplastic agents. Am J Health Syst Pharm 2002;59:270-7. PMID: 11862639

44. Boiano JM, Steege AL, Sweeney MH. Adherence to safe handling guidelines by health care workers who administer antineoplastic drugs. J Occup Environ Hyg 2014;11:728-40. doi: 10.1080/15459624.2014.916809

45. Vyas N, Turner A, Clark JM, Sewell GJ. Evaluation of a closed-system cytotoxic transfer device in a pharmaceutical isolator. J Oncol Pharm Pract 2014;22:10-9. doi: 10.1177/1078155214544993

46. Sessink PJ, Trahan J, Coyne JW. Reduction in surface contamination with cyclophosphamide in 30 US hospital pharmacies following implementation of a closed-system drug transfer device. Hosp Pharm 2013;48:204-12. doi: 10.1310/hpj4803-204

47. Simon N, Vasseur M, Pinturaud M, Soichot M, Richeval C, Humbert L, Lebecque M, Sidikou O, Barthelemy C, Bonnabry P, Allorge D, Décaudin B, Odou P. Effectiveness of a closed-system transfer device in reducing surface contamination in a new antineoplastic drug - compounding unit: a prospective, controlled, parallel study. PLoS One 2016;11:e0159052. doi: 10.1371/journal.pone.0159052

48. Barek J, Cvacka J, de Méo M, Laget M, Michelon J, Castegnaro M. Chemical degradation of wastes of antineoplastic agents amsacrine, azathioprine, asparaginase and thiotepa. Ann Occup Hyg 1998;42:259-66. doi: 10.1016/ S0003-4878(98)00023-4

49. Benvenuto JA, Connor TH, Monteith DK, Laidlaw JL, Adams SC, Matney TS, Theiss JC. Degradation and inactivation of antitumor drugs. J Pharm Sci 1993;82:988-91. doi: 10.1002/ jps.2600821003

50. Castegnaro M, De Méo M, Laget M, Michelon J, Garren L, Sportouch MH, Hansel S. Chemical degradation of wastes of antineoplastic agents. 2: six anthra-cyclines: darubicin, doxorubicin, epirubicin, pirarubicin, aclarubicin, and daunorubicin. Int Arch Occup Environ Health 1997;70:37884. doi: $10.1007 / \mathrm{s} 004200050232$

51. Hansel S, Castegnaro M, Sportouch MH, De Méo M, Milhavet JC, Laget M, Duménil G. Chemical degradation of wastes of antineoplastic agents: cyclophosphamide, ifosfamide and melphalan. Int Arch Occup Env He 1997;69:109-14. doi: 10.1007/s004200050124

52. Lamerie TQ, Nussbaumer S, Décaudin B, Fleury-Souverain S, Goossens JF, Bonnabry P, Odou P. Evaluation of decontamination efficacy of cleaning solutions on stainless steel and glass surfaces contaminated by 10 antineoplasic agents. Ann Occup Hyg 2013;57:456-69. doi: 10.1093/ annhyg/mes087

53. Monteith DK, Connor TH, Benvenuto JA, Fairchild EJ, Theiss JC. Stability and inactivation of mutagenic drugs and 
their metabolites in the rine of patients administered antineoplastic therapy. Environ Mol Mutagen 1987;10:34156. PMID: 3315656

54. Shea JA, Shamrock WF, Abboud CA, Woodeshick RW, Nguyen LQ, Rubino JT, Segretario J. Validation of cleaning procedures for highly potent drugs. I. Losoxantrone. Pharm Dev Technol 1966;1:69-75. doi: 10.3109/10837459609031420

55. Touzin K, Bussières JF, Langlois E, Lefebvre M, Métra A. Pilot study comparing the efficacy of two cleaning techniques in reducing environmental contamination with cyclophosphamide. Ann Occup Hyg 2010;54:351-9. doi: 10.1093/annhyg/meq004

56. Lunn G, Sansone EB, Andrew AW, Hellwig LC. Degradation and disposal of some antineoplastic drugs. J Pharm Sci 1989;78:652-9. doi: 10.1002/jps.2600780811

57. Raghavan R, Burchett M, Loffredo D, Mulligan JA. Lowlevel (PPB) determination of cisplatin in cleaning validation (rinse water) samples. II. A high-performance liquid chromatographic method. Drug Dev Ind Pharm 2000;26:42940. doi: 10.1081/DDC-100101250

58. Ladeira C, Viegas S, Costa-Veiga A. How to deal with uncertainties regarding the occupational exposure to antineoplastic mixtures: additive effect should always be considered? In: Topical Scientific Workshop - New Approach Methodologies in Regulatory Science, Proceedings of a Scientific Workshop Helsinki, 19-20 April 2016 [displayed 17 August 2018]. Available at https://echa.europa.eu/ documents/10162/22816069/scientific_ws_proceedings_ en.pdf

59. Cavallo D, Ursini CL, Perniconi B, Francesco AD, Giglio M, Rubino FM, Marinaccio A, Iavicoli S. Evaluation of genotoxic effects induced by exposure to antineoplasic drugs in lynphocytes and exfoliated buccal cells of oncologu nurses and pharmacy employees. Mutat Res 2005;587:45-51. doi: 10.1016/j.mrgentox.2005.07.008

60. Fučić A, Jazbec A, Mijić A, Šešo-Šimić D, Tomek R. Cytogenetic consequences after occupational expo-sure to antineoplastic drugs. Mutat Res 1998;416:59-66. doi: 10.1016/S1383-5718(98)00084-9

61. Roland C, Ouellette-Frève JF, Plante C, Bussières J-F. Surface contamination in a teaching hospital: a 6 year perspective. Pharm Technol Hosp Pharm 2016;1:187-93. doi: 10.1515/pthp-2016-0016

62. Viegas S, Ladeira C, Costa-Veiga A, Perelman J, Gajski G. Forgotten public health impacts of cancer - an overview. Arh Hig Rada Toksikol 2017;68:287-97. doi: 10.1515/aiht-201768-3005

63. Cavallo D, Ursini CL, Omodeo-Salè E, Iavicoli S. Micronucleus induction and FISH analysis in buccal cells and lymphocytes of nurses administering antineoplastic drugs. Mutat Res 2007;628:11-8. doi: 10.1016/j. mrgentox.2006.10.014

64. Gajski G, Ladeira C, Gerić M, Garaj-Vrhovac V, Viegas S. Genotoxicity assessment of a selected cytostatic drug mixture in human lymphocytes: a study based on concentrations relevant for occupational exposure. Environ Res 2018;161:2634. doi: 10.1016/j.envres.2017.10.044

65. Sabatini L, Barbieri A, Tosi M, Violante FS. A new highperformance liquid chromatographic/electrospray ionization tandem mass spectrometric method for the simultaneous determination of cyclophosphamide, methotrexate and 5 -fluorouracil as markers of surface contamination for occupational exposure monitoring. J Mass Spectrom 2005;40:669-74. doi: 10.1002/jms.840

66. Castagne V, Habert H, Abbara C, Rudant E, BonhommeFaivre L. Cytotoxics compounded sterile preparation control by HPLC during a 16-month assessment in a French university hospital: importance of the mixing bags step. J Oncol Pharm Pract 2011;17:191-6. doi: $10.1177 / 1078155210376846$

67. Dal Bello F, Santoro V, Scarpino V, Martano C, Aigotti R, Chiappa A, Davoli E, Medana C. Antineoplastic drugs determination by HPLC-HRMS(n) to monitor occupational exposure. Drug Test Anal 2016;8:730-7. doi: 10.1002/ dta. 1827

\section{Profesionalna izloženost citotoksičnim lijekovima: koliko je važno čišćenje površina za njezino sprječavanje odnosno smanjenje}

U zdravstvenih radnika koji pripremaju ili primjenjuju citotoksične lijekove zdravstveni rizici zbog izloženosti su realni, čak i pri dozama nižima od onih koje se primjenjuju u bolesnika jer, načelno, nijedna doza nije neškodljiva za zdravlje. Najčešći i najproblematičniji put izlaganja jest koža, napose zato što radne površine gdjekad ostanu kontaminirane i nakon njihova čišćenja. Cilj ovoga preliminarnog istraživanja bio je pokazati koliko je važno osmisliti djelotvoran protokol za dekontaminaciju na temelju pokazatelja kontaminacije radnih površina jedinice za pripremu lijekova, jedinice za njihovu primjenu te bolesničkoga zahoda onkološke ambulante trima najčešćim citotoksičnim onkološkim lijekovima: ciklofosfamidom, 5-fluoroacilom i paklitakselom. Uzorke smo prikupljali prije rada s lijekovima te tri sata od početka rada $\mathrm{s}$ njima te ih analizirali tekućinskom kromatografijom s detektorom s nizom dioda (engl. high performance liquid chromatography with diode array detection, krat. HPLC-DAD). Od 29 uzoraka prikupljenih prije rada s lijekovima, 23 su bila kontaminirana, od kojih pet s više lijekova. Od 30 uzoraka prikupljenih tri sata nakon početka rada s lijekovima, njih 25 bilo je kontaminirano, od kojih osam s više lijekova. Kontaminacija površina prije i nakon početka rada s lijekovima nije bila značajno različita, što upozorava na raširenu kontaminaciju i nedjelotvorno čišćenje. Stoga bi trebalo revidirati postojeći protokol čišćenja i rukovanja lijekovima te svesti kontaminaciju na najmanju moguću mjeru. 